solely on their mental processes. Collision statistics show that, among the unsuccessful, they are in a great majority.' 2

\title{
REFERENCES
}

1 Webster, J. R. (1962). Discussion. This Journal, 15, 272.

2 Wylie, F. J. (1966). True motion and relative motion. This Journal, 19, 32.

\section{Collisions in Western European Rivers}

\author{
Captain Archie Horka \\ (Master, United States Lines, Ret.)
}

Captain A. Wepster's able and professional analysis of this subject, contained in the January issue of the Journal, confirms what many seamen have long known. That these rivers-the Schelde, the New Waterweg, the Weser and, finally, the teeming Elbe, from Brunsbuttel seaward-are the world's most difficult and demanding stretches of navigation for seamen and pilots. The Captain's excellent treatment focuses attention on this and in his final paragraph he offers several considerations which, if followed, could reduce the number of collisions.

I refer to page 29; 'Improving River and Port Authority Organizations and, if necessary, traffic control. On page 17, with reference to changing pilots in Flushing Roads in the Schelde; who has not, when proceeding outbound, 'overshot' the mark when approaching the pilot ground off the Commercial Harbour? There follows the business of making a complete circle midst moving traffic as an apologetic pilot comes a puffing to the bridge, showering abuse on the man he relieved because 'he failed to slow down in time'.

I would add a specific recommendation to those offered by Captain Wepster: For vessels outbound from the Schelde, to disembark their pilots and take on Oostgat or Wandelaar pilots at a point approximately three miles upriver, say at Sloehaven. A pilot station could be maintained at that point in the manner of the present pilot office at the Flushing Mole. Under the present system, say with an ebb tide under your stern, the cutter emerges from beyond the breakwater after an agonizing wait at which your pilot gives you a breezy wave and a 'Cheerio, Captain. The boat is coming. I go down now?' Unless you are a martinet, you mutter an assent and find yourself 'Queen of the May', literally in command of 'all you survey'. The pilots, meanwhile, are cheerily relieving one another at the ladder whilst you, drifting down on to the Nolle, are undecided whether to jump overboard or go blind!

Innumerable reasons would be presented why the status quo must prevail but a change is long overdue here. Lacking that, we must resign ourselves to a continuation of this 'Hurrah's Nest' that now prevails in Flushing Roads. 